\title{
Effect of post shooting application of urea and sulphate of potash at the denavelled, distal stalk end of banana cv. Borjahaji
}

\author{
I. SARMA, R. BORGOHAIN AND M. PHUKON
}

Krishi Vigyan Kendra, JORHAT (ASSAM) INDIA

Email : irasarma@gmail.com

\begin{abstract}
A field experiment was conducted at farmer's field under on farm trial during 2011-12, in Jorhat district of Assam, to study the impact of post shooting application of urea and sulphate of potash on the improvement of bunch weight of banana cultivar Borjahaji. The denavelled distal stalk end of the bunch was fed with urea, sulphate of potash blended with fresh cowdung soon after the fruit set. The results showed that when the bunch was fed with urea $(7.5 \mathrm{~g})$, sulphate of potash $(7.5 \mathrm{~g})$ blended with $500 \mathrm{~g}$ fresh cowdung $\left(\mathrm{T}_{4}\right)$ all the yield attributing characters viz., length of fingers, weight of fingers of first hand, weight of fingers of last hand, girth of fingers, weight of first hand, weight of last hand and bunch weight were maximum as compared to denavelling and application of cowdung only ( $\left.\mathrm{T}_{2}\right)$ and application of urea and cowdung at denavelled distal stalk end $\left(\mathrm{T}_{3}\right)$. The minimum of all these characters and bunch weight were obtained in control( $\left.\mathrm{T}_{1}\right)$ where male bud was retained till harvest. The results revealed that the nutrients moved from the blend into the bunch and significantly enhanced the weight of fruits and bunch. When the bunch was fed with urea $7.5 \mathrm{~g}$, sulphate of potash $7.5 \mathrm{~g}$ blended with cowdung $500 \mathrm{~g}\left(\mathrm{~T}_{4}\right)$ the response was 34.77 per cent, 11 per cent and 5.9 per cent increase in weight of bunch over the treatments $\mathrm{T}_{1}, \mathrm{~T}_{2}$ and $\mathrm{T}_{3}$, respectively.
\end{abstract}

Key words : Urea, De-navelling, Sulphate of potash, Finger, Cowdung, Bunch

How to cite this paper : Sarma, I., Borgohain, R. and Phukon, M. (2014). Effect of post shooting application of urea and sulphate of potash at the denavelled, distal stalk end of banana cv. Borjahaji. Asian J. Bio. Sci., 9 (2) : 296-298. 